\title{
Central Mesenteric Lymph Node BER-Ep4+ Cells in Colorectal Cancer: Challenge to Sentinel Node Concept?
}

\author{
Paulus G. Schurr ${ }^{a}$ Sophia Behnke ${ }^{a}$ Jussuf T. Kaifi ${ }^{a}$ Dean Bogoevski ${ }^{a}$ \\ Bjoern Link ${ }^{a}$ Oliver Mann ${ }^{a}$ Tim Strate $^{a} \quad K^{2}$ laus Pantel ${ }^{b}$ Jakob R. Izbicki ${ }^{a}$ \\ Emre Yekebas $^{a}$ \\ ${ }^{a}$ Department of General, Visceral and Thoracic Surgery, and ${ }^{\mathrm{b}}$ Institute of Tumor Biology, \\ University Medical Center Hamburg-Eppendorf, Hamburg, Germany
}

\section{Key Words}

Colorectal carcinoma - Lymph node metastasis •

Mesenteric lymph nodes · Micrometastases · BER-Ep4 tinels of disease not amenable to extended lymphadenectomy and might identify patients at risk of distant organ recurrence.

Copyright $\odot 2007$ S. Karger AG, Basel

\begin{abstract}
Background: The role of sentinel lymph nodes in colorectal cancer remains unclear. Methods: Cryosections from central para-aortic mesenterial lymph nodes were stained using mAb BER-Ep4. Overall survival and distant recurrence were calculated using Kaplan-Meier plots. Results: All patients ( $n=48$ ) were free of distant metastases and curatively resected (R0). 23 pN0, 13 pN1 and 12 pN2 stages were found. $21 / 48$ patients (44\%) showed BER-Ep4+ cells in their central lymph nodes (7/23 pN0, 8/13 pN1, 6/12 pN2). In 6/23 pN0 patients, BER-Ep4+ cells were also found in locoregional nodes ( $p=0.03$, Fisher's exact test). $p N$ status predicted overall survival ( $p=0.006$, Kaplan-Meier curve, log-rank test). An impact was exerted by central mesenteric BER-Ep4+ cells on overall survival ( $p=0.009$ in $p N 0$ patients, $p=0.07$ for all $p N$ ) and distant recurrence-free survival ( $p=0.001$ in $p N 0$ patients, $p=0.007$ for all $p N)$. Multivariate analysis showed an independent prognostic effect on overall survival in pNO patients $(p=0.022)$. Conclusion: Central lymph nodes are sen-
\end{abstract}

\section{Introduction}

Metastases are a major phenomenon of disease progression and may constitute treatment failure in patients with colorectal carcinoma [1]. At primary surgery, resectable cancer is ideally treated by resection of the primary tumour and by lymphadenectomy comprising all virtually involved nodes [2]. Even in T1 cancer, lymph node involvement is said to be as high as $10 \%$ [3]. Sentinel lymph node sampling is thought to facilitate customized lymphadenectomy. This concept is accepted for melanoma and breast cancer but is not used routinely for colorectal cancer [4]. Rather, recent analyses have shown that it is unlikely to improve risk stratification in resectable colon cancer [5]. With up-coming laparoscopic surgery, the extent of lymph node dissection with particular attention to central mesenteric lymph nodes is lively discussed [6]. The TNM Classification allows for quantitative assess-

\section{KARGER}

Fax +4161306 1234 E-Mail karger@karger.ch www.karger.com
(ㄷ) 2007 S. Karger AG, Basel

0253-4886/07/0241-0019\$23.50/0

Accessible online at:

www.karger.com/dsu
Paulus G. Schurr, MD

Department of General, Visceral and Thoracic Surgery

University Medical Center Hamburg-Eppendorf

Martinistrasse 52, DE-20246 Hamburg (Germany)

Tel. +49 4042803 2401, Fax +49 4042803 4995, E-Mail schurr@uke.uni-hamburg.de 
ment of locoregional lymph node involvement and defines affection of up to 3 lymph nodes as $\mathrm{pN} 1$ and beyond that as pN2 [7]. The Japanese classification features the site of the metastasized lymph node as a prognostic marker [8]. In modern curative surgery, local recurrence should be a rare event in rectal carcinoma and should be virtually absent in colon cancer [9]. However, even at low postsurgical histopathological stages, recurrent disease is encountered [10]. Thus, effort continues towards a refined staging. Early detection of micrometastatic tumour dissemination might identify patients at increased risk of developing recurrent disease. Monoclonal antibodies against tumour-associated epithelial antigens can be used to detect disseminated tumour cells in lymph nodes that are free of metastasis on routine histopathological examination in a variety of gastrointestinal carcinomas [11-18]. The discussion about sentinel lymph node analysis is of high clinical relevance, as immunostaining of all lymph nodes retrieved in colon or rectal resections is costly and time-consuming. The predictive value of a positive or negative sentinel lymph node is, however, controversely discussed [19-21]. In order to heighten the accuracy of sentinel lymph node findings, immunohistochemistry has been applied to these lymph nodes, with little better results $[5,20]$. In contrast, in previous studies micrometastases have been shown to be predictive for outcome independent of their localization in colorectal cancer [22]. Little is known about micrometastases in central mesenteric lymph nodes among patients with localized colorectal disease. Therefore our approach was to examine the micrometastatic spread in these central para-aortic lymph nodes in a series of 48 patients with curatively resected colorectal cancer.

\section{Patients and Methods}

The ethical committee of the chamber of physicians in Hamburg approved this study. Informed consent was obtained from all the patients at inclusion into the study. 48 patients with colorectal cancer free of distant metastases (M0) underwent R0 resections and central lymph node sampling. Patients with pN3 metastases to central para-aortic lymph nodes were excluded.

Tumour stage and grade were classified according to the 6th Tumour Node Metastasis (TNM) Classification 2002 of the International Union Against Cancer.

Follow-up was either performed by interviewing the patients or their general practitioners. Follow-up evaluations included a physical examination, abdominal ultrasonography, computed tomography of the abdomen and studies of tumour markers.

\section{Tissue Preparation}

During lymphadenectomy, central para-aortic mesenteric lymph nodes were systematically sampled by the assistant surgeon: Pre- and left-sided para-aortic connective tissue was harvested during the surgical steps of central arterial ligation. On the back table, lymph nodes were located by palpation or by cutting the central mesenterial tissue into slices. Either one $(n=25)$ or two $(n=23)$ central lymph nodes per patient were sampled and analyzed. Peripheral lymph nodes were only taken for cryopreservation (one half, the other half was separately formalin-fixed for the histopathological haematoxylin and eosin (HE) stain), if they did not reveal gross disease.

One half of the lymph node was separately formalin fixed and later embedded in paraffin for routine histopathological analysis by HE staining. The rest was snap-frozen in liquid nitrogen within $30 \mathrm{~min}$ after removal and stored at $-80^{\circ} \mathrm{C}$ until use. Only lymph nodes with no macroscopic evidence of metastasis were used for this analysis. The antibody BER-Ep4 (IgG1; Dako, Hamburg, Germany) was used as described previously [11]. Briefly, Ber-Ep4 is an antibody against two glycopolypeptides of 34 and $39 \mathrm{kDa}$ on the surface and the cytoplasm of all epithelial cells except for the superficial layers of squamous epithelia, parietal cells and hepatocytes. The antibody does not react with mesenchymal tissue, including lymphoid tissue [23]. Two cryostat sections of about $5 \mu \mathrm{m}$ thickness were cut at three different levels in each node and transferred onto glass slides treated with 3-triethoxysilylpropylamine (Merck, Darmstadt, Germany). Lymph nodes from 21 control patients with non-epithelial tumours or inflammatory diseases consistently stained negative. In a study by Rosenberg et al. [22] antibodies against BER-Ep4, CK and CEA were used in stage I and II colorectal cancer and differences in staining and prognostic value were marginal. Sections of normal colon mucosa served as positive staining control and isotype-matched, irrelevant murine monoclonal antibodies served as negative controls (purified immunoglobulin mouse myeloma protein for IgG1; Sigma, Deisenhofen, Germany). The antibody reaction was developed with the alkaline phosphatase-anti-alkaline phosphatase technique combined with the new fuchsin stain (Sena, Heidelberg, Germany) for the visualization reaction $[13,23]$. The slides were evaluated in a blinded fashion by two observers independently (P.S., S.B.). For $98 \%$ of the slides, the observers' evaluations were identical; the remaining slides were re-evaluated, and a consensus decision was made.

\section{Microscopy}

Minimal tumour cell invasion in a lymph node that was considered to be tumour-free by HE staining was defined as the presence of BER-Ep4+ single cells or a cluster of cells or a solid aggregate of micrometastasis with positive BER-Ep4 staining. The current classification of immunohistochemical lymph node findings describes lesions of up to $2 \mathrm{~mm}$ in size and indicates them as (mi), whereas single cells or clusters of cells of $<0.2 \mathrm{~mm}$ are defined as isolated tumour cells [16, 24, 25].

\section{Statistical Analysis}

We used the SPSS $11.5^{\circ}$ for Windows (SPSS Inc., 1999) for statistical analysis. Associations between categorical variables were assessed by Fisher's exact test and $\chi^{2}$ test. The Kaplan-Meier plot was used to estimate the occurrence probability of events (death, local and distant organ recurrence) for overall survival, distant 
Table 1. Patients' characteristics

\begin{tabular}{|c|c|c|c|c|}
\hline & \multicolumn{3}{|c|}{ Central LN BER-Ep4 + cells } & \multirow[t]{2}{*}{ p value ${ }^{*}$} \\
\hline & no & yes & total & \\
\hline Total & $27(56)$ & $21(44)$ & 48 & \\
\hline \multicolumn{5}{|l|}{ Tumour depth } \\
\hline pT1 & $7(100)$ & 0 & 7 & \multirow[t]{4}{*}{$0.06^{*}$} \\
\hline pT2 & $6(60)$ & $4(40)$ & 10 & \\
\hline pT3 & $12(48)$ & $13(52)$ & 25 & \\
\hline pT4 & $2(33)$ & $4(67)$ & 6 & \\
\hline \multicolumn{5}{|l|}{ Histopathological lymph node status } \\
\hline pN0 & $16(70)$ & $7(30)$ & 23 & \multirow[t]{3}{*}{$0.17^{*}$} \\
\hline $\mathrm{pN} 1$ & $5(38)$ & $8(62)$ & 13 & \\
\hline $\mathrm{pN} 2$ & $6(50)$ & $6(50)$ & 12 & \\
\hline \multicolumn{5}{|l|}{ Sex } \\
\hline Male & $12(46)$ & $14(54)$ & 26 & \multirow[t]{2}{*}{$0.11^{* *}$} \\
\hline Female & $15(68)$ & $7(31)$ & 22 & \\
\hline \multicolumn{5}{|l|}{ Age at primary surgery } \\
\hline$<60$ years & $13(59)$ & $9(40)$ & 22 & \multirow[t]{2}{*}{$0.48^{* *}$} \\
\hline$\geq 60$ years & $14(53)$ & $12(46)$ & 26 & \\
\hline \multicolumn{5}{|l|}{ Localization } \\
\hline Right hemicolon and transverse colon & $4(33)$ & $8(67)$ & 12 & \multirow[t]{2}{*}{$0.17^{* *}$} \\
\hline Left colon and rectum & $23(64)$ & $13(36)$ & 36 & \\
\hline
\end{tabular}

Values in parentheses are percentage. ${ }^{*} \chi^{2}$ test. ${ }^{* *}$ Fisher's exact test.

recurrence-free survival and local recurrence-free survival. For comparison, log-rank tests were performed. The Cox proportional hazards model was used for multivariate analysis.

\section{Results}

\section{Patients' Characteristics}

Data about sex, age, primary tumour site, depth of the primary tumour, histopathological lymph node status and presence of lymph node BER-Ep4+ cells are depicted in table 1. Sex distribution was almost equal (26 men and 22 women) and median age was 60 years (range 29-86). Predominantly, pT3 stage was observed. Central lymph node micrometastases seemed to be associated with higher $\mathrm{pT}$ stage, whereas no such correlation was observed with $\mathrm{pN}$ status $(\mathrm{p}=0.06$ and $\mathrm{p}=0.17$, respectively). Fifty percent of the patients were free of histopathological lymph node metastases (pN0, 23/48, $48 \%)$.

\section{Lymph Node Retrieval}

Median surgical retrieval of lymph nodes in the resection specimen was 18 (range 12-34) and a total of 729 lymph nodes were contained in all histopathological specimens. 153 lymph nodes were judged macroscopically tumour-free during surgery and collected for cryopreservation and immunohistochemistry. 71 lymph nodes were dissected pre- and para-aortically and sampled during central ligation of the arterial supply. Moreover, 82 peripheral locoregional lymph nodes were harvested. At least 1 central and 1 peripheral lymph node were sampled per patient for cryopreservation.

\section{Recurrence}

Distant tumour recurrence was the determining form of recurrence and turned out to correlate with the onset of BER-Ep4+ cells. Recurrence was observed in $5 / 23,7 / 13$ and $8 / 12$ individuals with $\mathrm{pN} 0, \mathrm{pN} 1$ and $\mathrm{pN} 2$ status, respectively. This correlation was highly significant $(\log$-rank $\mathrm{p}=0.0036)$. Thus, 5 recurrences occurred in the pN0 group. BER-Ep4 status revealed a subgroup of $\mathrm{pN} 0$ patients at particular risk for recurrence: $4 / 7 \mathrm{pa}-$ tients with BER-Ep4+ cells recurred, whereas only 1/16 patients without did after 37 months. Therefore, the positive predictive value (PPV) would be $80 \%$ (4 out of 5 who recurred) among pN0 patients. In contrast, $\mathrm{pN}$ was also predicting recurrence with a PPV of $15 / 25=$ $60 \%$ ( 15 subjects out of 25 positive pN status recurred). 
Table 2. Contingencies for central mesenteric and locoregional lymph node (LN) BER-Ep 4+ cells

\begin{tabular}{|c|c|c|c|c|c|}
\hline & & \multicolumn{3}{|c|}{ Central LN BER-Ep4+ cells } & \multirow[t]{2}{*}{$\mathrm{p}$ value* } \\
\hline & & no & yes & total & \\
\hline \multirow[t]{4}{*}{ All $\mathrm{pN}$} & \multicolumn{4}{|c|}{ Peripheral LN BER-Ep4+ cells } & $<0.01$ \\
\hline & No & $20(83)$ & $4(17)$ & 24 & \\
\hline & Yes & $7(29)$ & $17(71)$ & 24 & \\
\hline & Total & $27(56)$ & $21(44)$ & 48 & \\
\hline \multirow[t]{4}{*}{ pNo } & \multicolumn{4}{|c|}{ Peripheral LN BER-Ep4+ cells } & 0.03 \\
\hline & No & $11(92)$ & $1(8)$ & 12 & \\
\hline & Yes & $5(46)$ & $6(54)$ & 11 & \\
\hline & Total & $16(70)$ & $7(30)$ & 23 & \\
\hline \multirow[t]{4}{*}{ pN1 } & \multicolumn{4}{|c|}{ Peripheral LN BER-Ep4+ cells } & 0.02 \\
\hline & No & $5(72)$ & $2(28)$ & 7 & \\
\hline & Yes & 0 & $6(100)$ & 6 & \\
\hline & Total & $5(39)$ & $8(61)$ & 13 & \\
\hline \multirow[t]{4}{*}{ pN2 } & \multicolumn{4}{|c|}{ Peripheral LN BER-Ep4+ cells } & 0.08 \\
\hline & No & $4(80)$ & $1(20)$ & 5 & \\
\hline & Yes & $2(29)$ & $5(71)$ & 7 & \\
\hline & Total & $6(50)$ & $6(50)$ & 12 & \\
\hline
\end{tabular}

Values in parentheses are percentage. ${ }^{*}$ Fisher's exact test.

\begin{tabular}{llccc}
\hline & \multicolumn{2}{l}{ Distant recurrence } & \multirow{2}{*}{ p value* $^{*}$} \\
\cline { 2 - 3 } & no & yes & total & \\
\hline $\begin{array}{l}\text { Total } \\
\text { pN status }\end{array}$ & $28(58)$ & $20(42)$ & 48 & \\
$\quad$ pN0 & $18(78)$ & $5(22)$ & 23 & 0.008 \\
$\quad$ pN1 or pN2 & $10(40)$ & $15(60)$ & 25 & \\
$\begin{array}{l}\text { Central LN BER-Ep4+ cells } \\
\quad \text { No }\end{array}$ & $20(74)$ & $7(26)$ & 27 & 0.013 \\
$\quad$ Yes & $8(38)$ & $13(62)$ & 21 & \\
\hline
\end{tabular}

Values in parentheses are percentages. ${ }^{*}$ Fisher's exact test.
Table 3. Dependence of distant recurrence on $\mathrm{pN}$ status and central lymph node (LN) BER-Ep4+ cells

\section{Presence of BER-Ep4+ Tumour Cells}

All 48 patients fulfilled the criteria of having no histopathological central lymph node involvement. Isolated BER-Ep4+ tumour cells (single cells and cluster of cells) and BER-Ep4+ micrometastases (up to about $2 \mathrm{~mm}$ in size) were discovered by immunohistochemistry in the central lymph nodes in 21/48 (44\%) patients. Among individuals with 2 central lymph nodes available for immunohistochemistry (23/48), concordant results were found in both lymph nodes. Looking at $\mathrm{pN} 0$ patients separately revealed that $7 / 23 \mathrm{pN} 0$ patients $(30 \%)$ showed
BER-Ep4+ tumour involvement in their central lymph nodes. In $8 / 13 \mathrm{pN} 1$ patients (61\%) and $6 / 12 \mathrm{pN} 2$ patients (50\%), BER-Ep4+ cells in central mesenteric lymph nodes were present. Peripheral lymph nodes showed BER-Ep4+ tumour involvement in $11 / 23 \mathrm{pN} 0$ patients (48\%). In $\mathrm{pN} 1$ and $\mathrm{pN} 2$ patients, BER-Ep4+ cells could also be observed in their fraction of apparently tumour-free nodes $(13 / 25$, $52 \%)$. This BER-Ep4+ cell appearance in peripheral locoregional lymph nodes was thus overall found in 24/48 (50\%) patients. Table 2 depicts the incidences of BEREp4+ tumour cells in central mesenteric and peripheral 


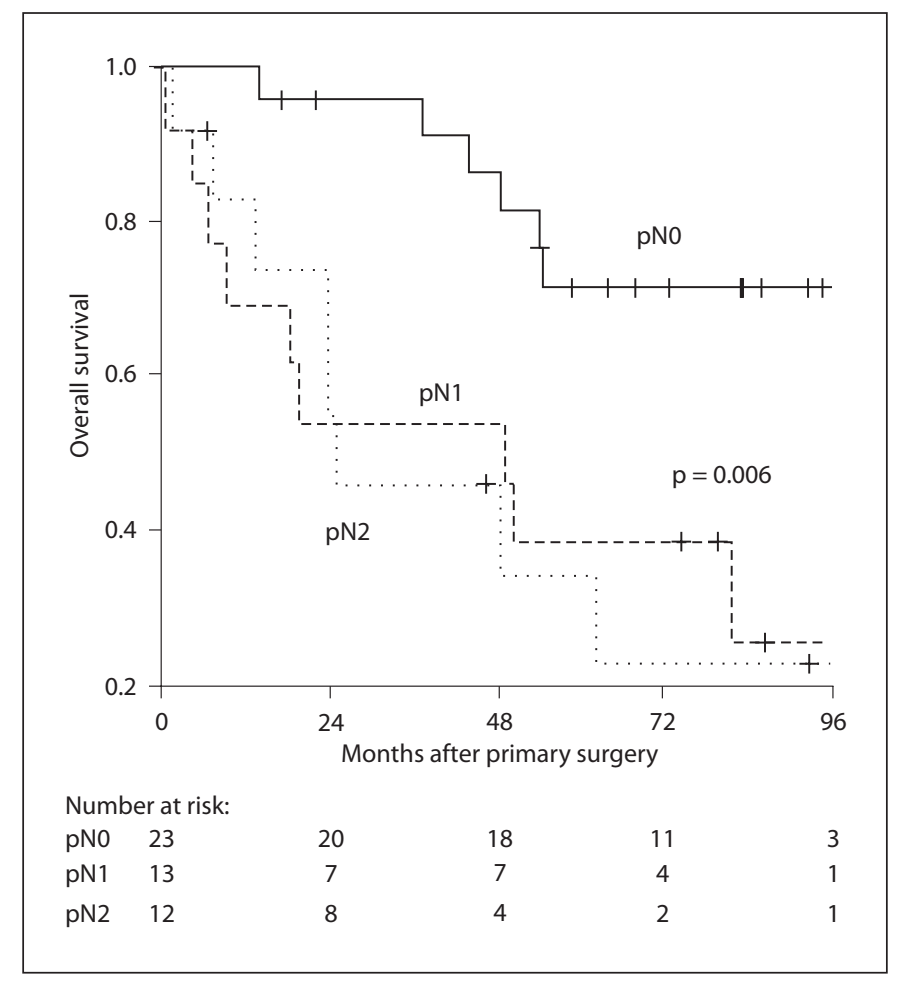

Fig. 1. Overall survival of 48 patients and different $\mathrm{pN}$ stages. The log-rank test was applied.

lymph nodes. In 4 patients (17\%) only central lymph nodes were affected by BER-Ep4+ cells. Mostly however, these BER-Ep4+ cells appeared concomitantly with peripheral BER-Ep4+ cells ( $p<0.01$, Fisher's exact test). This correlation could be observed in $\mathrm{pN} 0$ patients $(\mathrm{p}=$ 0.03 , Fisher's exact test), but was true also for $\mathrm{pN} 1$ and $\mathrm{pN} 2$ patients $(\mathrm{p}=0.02$ and 0.08 , respectively, table 2$)$. There was a significantly higher frequency of distant recurrence at presence of $\mathrm{pN} 1$ or $\mathrm{pN} 2$ stage over $\mathrm{pN} 0$ stage, and also at presence of BER-Ep4+ cells in central mesenteric lymph nodes $(\mathrm{p}=0.008$ and $\mathrm{p}=0.013$, respectively, Fisher's exact test, table 3 ).

\section{Survival Impact of pN Status}

$\mathrm{pN}$ status was a strong predictor for survival. Overall survival was much better for $\mathrm{pN} 0$ with a median overall survival time not reached in the Kaplan-Meier plot (6/23 death events after a median observation time of 64 months) versus 49 months (95\% CI: 12-86, 9/13 death events) in the pN1 group and 25 months (range 1-60, $8 / 12$ deaths events) in the $\mathrm{pN} 2$ group (log-rank test: $\mathrm{p}=$ 0.006 , fig. 1). Similarly, distant recurrence-free survival

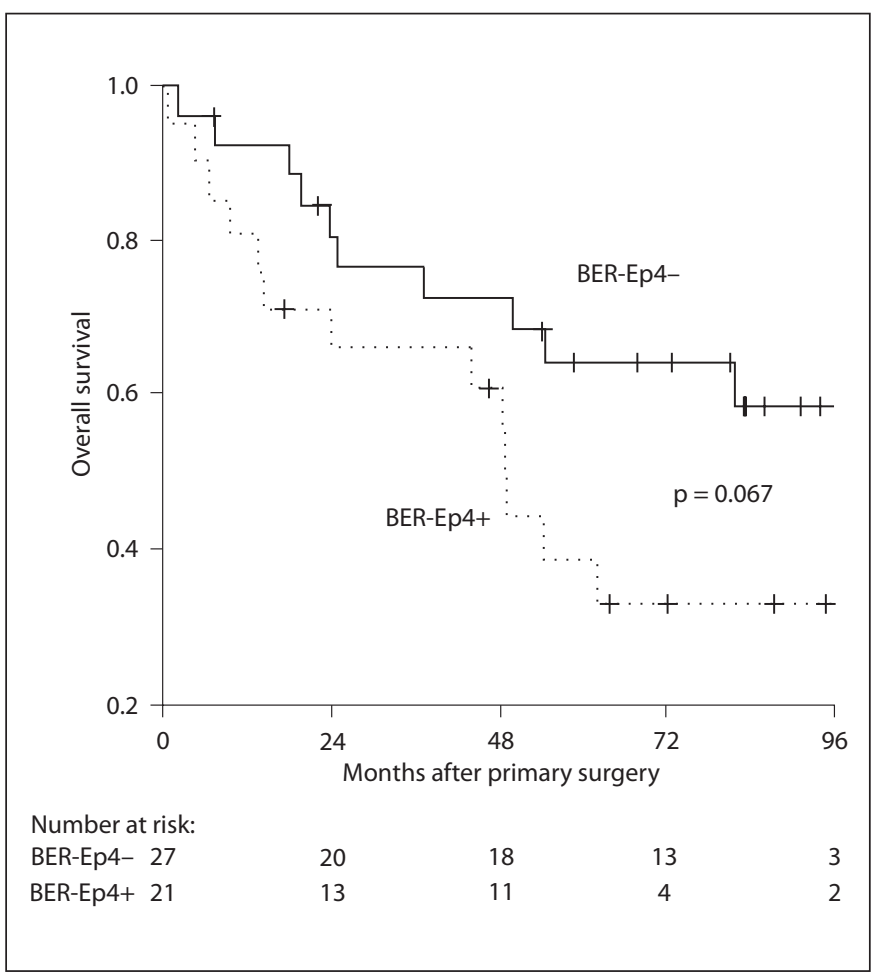

Fig. 2. Overall survival of 48 patients depending on presence or absence of BER-Ep4+ cells in their central mesenteric lymph nodes.

depended on $\mathrm{pN}$, as only 5/23 (22\%) distant recurrences occurred after a median observation of 64 months in the pN0 group, whereas $7 / 13$ events after a median of 70 months (95\% CI: 16-124) and 8/12 events after a median of 24 months (95\% CI: 21-26) occurred in the pN1 and $\mathrm{pN} 2$ subgroups, respectively ( $\mathrm{p}=0.04$, log-rank test, graph not shown). No significant impact of $\mathrm{pN}$ status could be observed for local recurrence-free survival (4/48 events, $p=0.92$ in log-rank test, graph not shown).

\section{Impact of Central Mesenteric BER-Ep4+Cells on Overall Survival, Distant Recurrence-Free Survival and Local Recurrence-Free Survival}

Central mesenteric lymph node involvement with BER-Ep4+ cells had an impact on overall survival, although not significant at the $5 \%$-level. Median survival was not reached in the negative group (10/27 death events after a median observation time of 73 months) versus 49 months (95\% CI: 48-50, 13/21 death events, log-rank test $p=0.067$, fig. 2). Distant recurrence-free survival was worse for patients with BER-Ep4+ cells in their central 


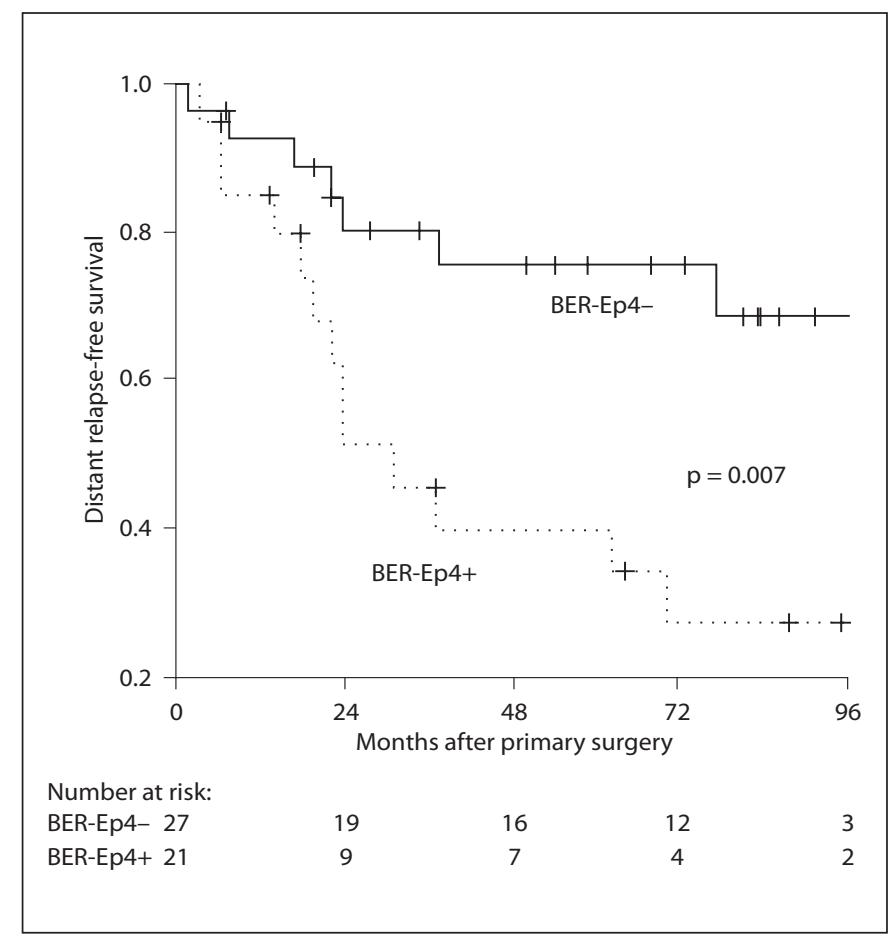

Fig. 3. Distant recurrence-free survival of 48 patients depending on presence or absence of BER-Ep4+ cells in their central mesenteric lymph nodes.

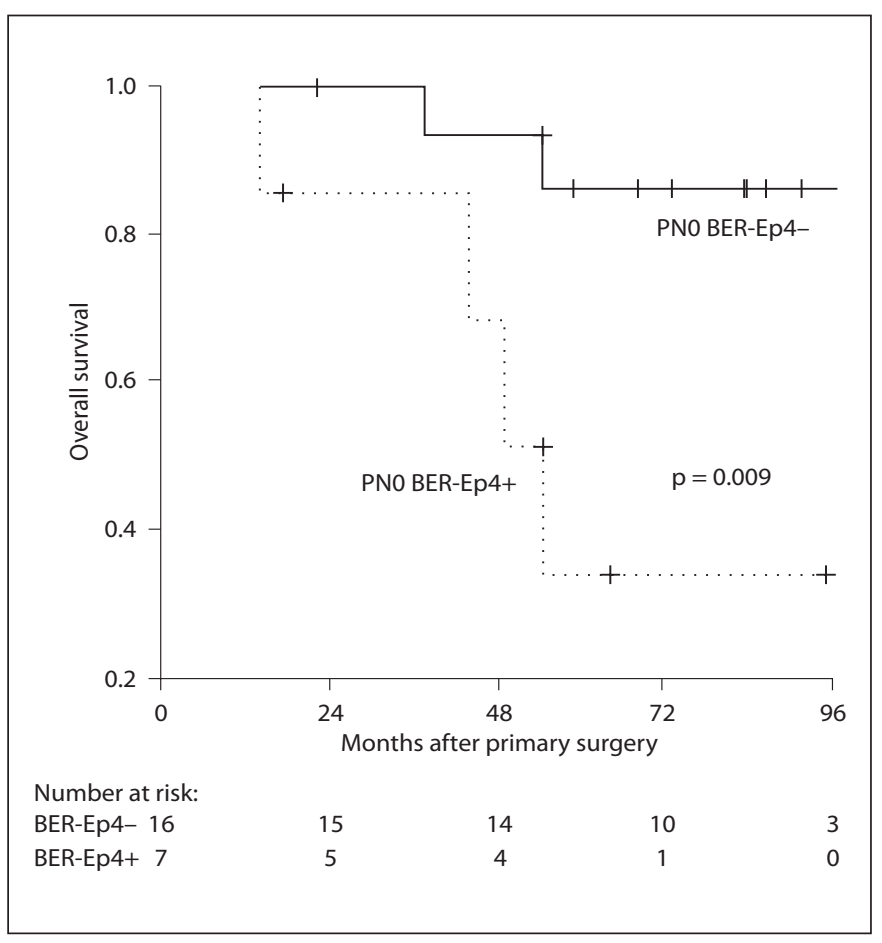

Fig. 4. Overall survival of $23 \mathrm{pN} 0$ patients depending on presence or absence of BER-Ep4+ cells in their central mesenteric lymph nodes.
Table 4. Cox multivariate regression analysis* for OS in pN0 patients

\begin{tabular}{llrl}
\hline & p value* & \multicolumn{1}{l}{$\begin{array}{l}\text { Relative } \\
\text { risk }\end{array}$} & 95\% CI \\
\hline Age at primary surgery: $\geq 60$ vs. $<60$ years & 0.190 & 8.155 & $0.354-187.653$ \\
Sex: female vs. male & 0.571 & 0.466 & $0.033-6.554$ \\
pT stage: pT3/4 vs. pT1/2 & 0.414 & 1.967 & $0.388-9.970$ \\
Central LN BER-Ep4+ cells & 0.022 & 18.636 & $0.529-227.132$ \\
\hline
\end{tabular}

mesenteric lymph nodes. Patients without suffered distant recurrence in $7 / 27$ cases after a median observation time of 54 months, versus patients with BER-Ep4+ cells who suffered recurrence in 13/21 cases after a median of 31 months (95\% CI: 13-49, fig. 3, $\mathrm{p}=0.007$ ). Local recurrence was rare (4/48 cases, 1 case was BER-Ep4+ and 3 were BER-Ep4-) and median local recurrence-free survival did not show dependence on central mesenteric lymph node BER-Ep4+ positivity (log-rank test: $\mathrm{p}=0.580$, curve not shown). Looking at pN0 patients separately, revealed a significant prognostic impact of central BER-
Ep4+ cells on both overall survival and distant recurrence-free survival ( $\mathrm{p}=0.009$ and 0.001 , respectively, fig. 4,5$)$.

\section{Impact of Peripheral BER-Ep4+Cells on Overall}

Survival, Distant Recurrence-Free Survival and Local

Recurrence-Free Survival

BER-Ep4+ cells in peripheral locoregional lymph nodes revealed no significant impact on overall survival and local recurrence-free survival. BER-Ep4+ cells were observed in $24 / 48$ patients (50\%) and comparison of 


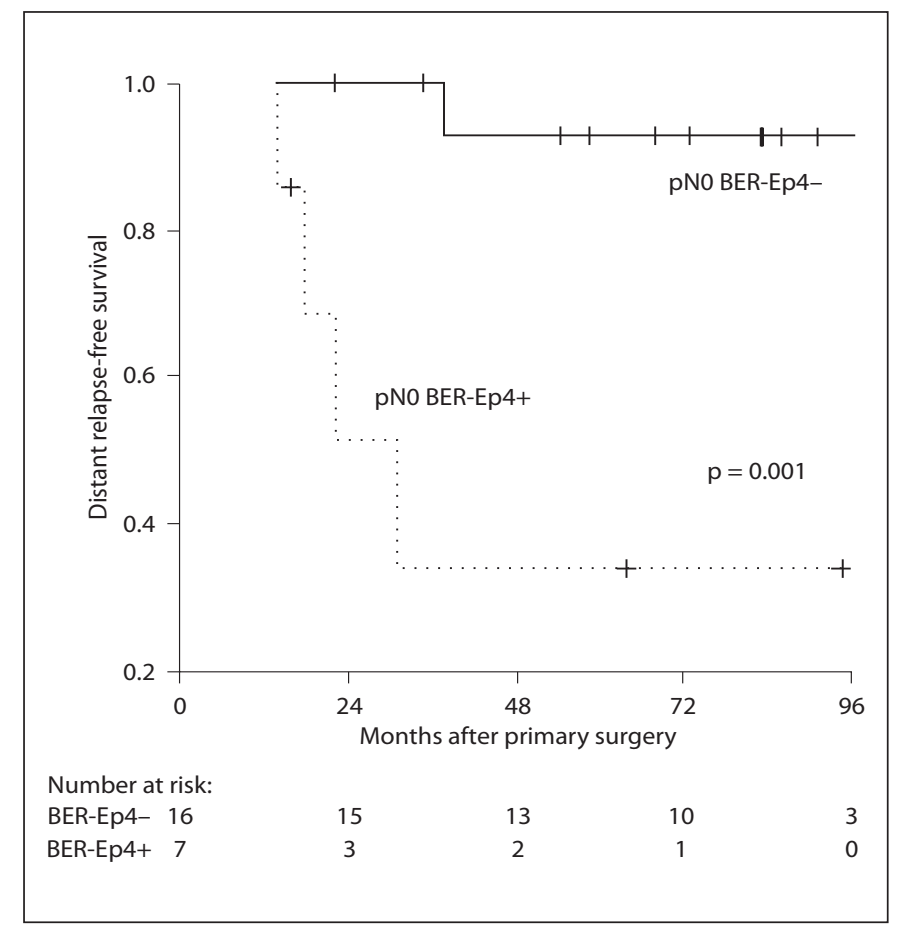

Fig. 5. Distant recurrence-free survival of $23 \mathrm{pN} 0$ patients depending on presence or absence of BER-Ep4+ cells in their central mesenteric lymph nodes.

overall survival times showed a median of 54 months (95\% CI: 44-58) and 81 months (95\% CI: 61-105) for BER-Ep4+ and BER-Ep4- patients, respectively ( $\mathrm{p}=$ 0.64 , log-rank test, curve not shown). Distant recurrence was observed after a median observation time of 50 months in 7/24 BER-Ep4+ patients and after 31 months in 13/24 BER-Ep4- patients, respectively ( $\mathrm{p}=0.12$, logrank test). Local recurrence was observed in 4/48 patients, and median local recurrence-free survival did not depend on peripheral BER-Ep4+ cells (log-rank test: $\mathrm{p}=$ $0.39)$.

\section{Multivariate Analysis}

Central BER-Ep4+ cells showed an independent prognostic influence in 23/48 pN0 cancer patients on overall survival in the Cox regression analysis $(\mathrm{p}=0.022$, table 4). No independent prognostic impact was observed for distant metastases-free survival and local recurrencefree survival. BER-Ep4+ cells did not remain significant for overall survival in Cox regression analysis for pooled $\mathrm{pN} 0$ and $\mathrm{pN} 1$ patients ( $\mathrm{p}=0.206$, data not shown).

\section{Discussion}

Currently, much effort is being put into clinical evaluation of sentinel lymph node biopsy, with different methods of sentinel lymph node detection and in vivo and ex vivo approaches in different entities [19, 26-28]. The common determinant of these studies seems to be a tailored lymph node dissection by means of selective lymph node analysis of lymph nodes 'neighbouring' the primary tumours, thus avoiding excessive lymphatic tissue resection in selected patients. However, very recently in a randomized trial [5] accuracy and clinical relevance of sentinel lymph node sampling have been heavily questioned in colorectal surgery. Particularly in colon cancer the relevance of reducing the extent of lymph node dissection is unclear, in contrast to breast cancer and melanoma, where sentinel lymph node assessment sensibly helps sparing unnecessary radical lymphadenectomies in patients. It has been argued, however, that in minimally invasive colorectal surgery, a reduction of lymph node dissection might be desirable and therefore analysis of sentinel lymph nodes might be beneficial [27].

$\mathrm{pN}$ status is the most powerful predictor of prognosis and has been respected by the UICC/AJCC consensus classification in that it separates stage II from stage III cancer. Its importance extends to overall survival as well as to distant recurrence-free and local recurrence-free survival [5]. However, its significance for recurrence has been probably overestimated in the past and in latest studies the significance of the circumferential resection margin and the $\mathrm{R}$ status has been recognized as a very powerful determinant of recurrence [7]. While the circumferential resection margin as well as the radial aboral mucosal margin are in the hands of the surgeon, lymph node invasion often indicated spreading disease and thus adjuvant therapies might make all the difference. The idea behind sentinel lymph node sampling is that the tumour spreads per continuitatem, even in the lymph vessels and nodes. This has now been heavily questioned in a recent multicentre study where sentinel lymph nodes were analyzed employing both histopathological and immunohistochemical methods [5]. We therefore tried another methodological strategy in order to rule out undetected disease in lymphadenectomy specimens. In a limited series of 48 patients who had given informed consent for retrieval of 'central lymph nodes' during surgery, we analyzed those 'central' lymph nodes by means of $\mathrm{HE}$ staining and immunohistochemistry using mAb BEREp4. All patients enrolled in the study had localized disease without distant organ or distant lymph node metas- 
tasis, as defined by clinical and histopathological investigations. We hypothesized that any micrometastatic spread might extend to the central lymph nodes. To our perception, these lymph nodes might reveal more sensitively distant lymphatic spread and this method appears practicable as the area of central lymph node sampling is circumscript in colorectal disease. We postulated further that central lymph node involvement might reflect the patients' survival. We also stained locoregional lymph nodes in order to detect minimal tumour involvement. We observed that the central lymph nodes revealed a significant impact on overall survival and distant metastases-free survival. This impact proved particularly right for $\mathrm{pN} 0$ patients, where both overall survival and distant metastases-free survival were significantly impaired in the presence of BER-Ep4+ cells. However, also in pN1 and pN2 patients, distant recurrence-free survival depended on the presence of BER-Ep4+ cells in the central lymph nodes. In univariate analysis, a significant impact was observed irrespectively of the locoregional $\mathrm{pN}$ status of the specimen. This is a remarkable finding, since distant recurrence is the limiting prognostic factor after curative resections in colorectal cancer. As shown previously, locoregional cytokeratin-positive, CEA-positive and BEREp4+ cells in positive lymph nodes in pN0 colorectal can- cer patients are predictive for survival [22]. In our study, locoregional lymph nodes were not predictive for survival at the $5 \%$ level. This might be due to lower patient numbers than in the study mentioned above. Remarkably, the central lymph nodes did show significance in our study and this was particularly reflected in distant recurrencefree and overall survival. We can conclude that firstly, the central lymph node reflects systemic disease and is not amenable to radical resection as the locoregional lymph nodes, thus being useful for staging purposes. We secondly find a stronger prognostic impact for the central nodes than the peripheral ones in terms of micrometastatic seeding, which can be seen therefore as a common route for converging micrometastatic spread from the colorectal frame. Finally, decision to a customized adjuvant therapy might be facilitated at a more refined central lymph node staging.

\section{Acknowledgements}

We thank Dr. Michael Bubenheim for excellent statistical advice. Supported by Werner-Otto-Stiftung, Deutsche Forschungsgemeinschaft and Hamburger Krebsgesellschaft e.V.

\section{References}

1 Fang WL, Chang SC, Lin JK, et al: Metastatic potential in T1 and T2 colorectal cancer. Hepatogastroenterology 2005;52:16881691.

- 2 Sitzler PJ, Seow-Choen F, Ho YH, et al: Lymph node involvement and tumor depth in rectal cancers: an analysis of 805 patients. Dis Colon Rectum 1997;40:1472-1476.

3 Okabe S, Shia J, Nash G, et al: Lymph node metastasis in T1 adenocarcinoma of the colon and rectum. J Gastrointest Surg 2004;8: 1032-1039.

4 Sticca RD: Is there clinical value to sentinel lymph node sampling in colon cancer? J Clin Oncol 2006;24:841-842.

5 Bertagnolli M, Miedema B, Redston M, et al: Sentinel node staging of resectable colon cancer: results of a multicenter study. Ann Surg 2004;240:624-628.

6 Hida J, Yasutomi M, Maruyama T, et al: The extent of lymph node dissection for colon carcinoma: the potential impact on laparoscopic surgery. Cancer 1997;80:188-192.

7 Compton CC: Key issues in reporting common cancer specimens: problems in pathologic staging of colon cancer. Arch Pathol Lab Med 2006;130:318-324.
8 Hida J, Yasutomi M, Fujimoto K, et al: Comparison between the Japanese general rules and the TNM system in the regional lymph node classification of carcinoma of the colon. J Am Coll Surg 1996;183:611-615.

$\checkmark 9$ Read TE, Mutch MG, Chang BW, et al: Locoregional recurrence and survival after curative resection of adenocarcinoma of the colon. J Am Coll Surg 2002;195:33-40.

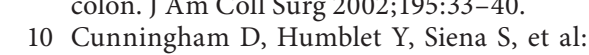
Cetuximab monotherapy and cetuximab plus irinotecan in irinotecan-refractory metastatic colorectal cancer. $\mathrm{N}$ Engl J Med 2004;351:337-345.

-11 Bogoevski D, Yekebas EF, Schurr P, et al: Mode of spread in the early phase of lymphatic metastasis in pancreatic ductal adenocarcinoma: prognostic significance of nodal microinvolvement. Ann Surg 2004; 240:993-1000.

$>12$ Hosch SB, Knoefel WT, Metz S, et al: Early lymphatic tumor cell dissemination in pancreatic cancer: Frequency and prognostic significance. Pancreas 1997;15:154-159.
13 Hosch SB, Stoecklein NH, Pichlmeier U, et al: Esophageal cancer: the mode of lymphatic tumor cell spread and its prognostic significance. J Clin Oncol 2001;19:1970-1975.

14 Hosch SB, Steffani KD, Scheunemann P, et al: Micrometastases from HBP malignancies and metastatic cancer. J Hepatobiliary Pancreat Surg 2002;9:583-591.

15 Izbicki JR, Passlick B, Hosch SB, et al: Mode of spread in the early phase of lymphatic metastasis in non-small-cell lung cancer: significance of nodal micrometastasis. J Thorac Cardiovasc Surg 1996;112:623-630.

$\checkmark 16$ Izbicki JR, Hosch SB, Pichlmeier U, et al: Prognostic value of immunohistochemically identifiable tumor cells in lymph nodes of patients with completely resected esophageal cancer. N Engl J Med 1997;337:11881194.

$\checkmark 17$ Izbicki JR, Hosch SB: Minimal dissemination of solid epithelial tumors: impact on staging and therapeutic strategy. Br J Surg 1997;84:897-898.

${ }_{18}$ Scheunemann P, Izbicki JR, Pantel K: Tumorigenic potential of apparently tumorfree lymph nodes. N Engl J Med 1999;340: 1687. 
-19 Bembenek A, Schneider U, Gretschel S, et al: Detection of lymph node micrometastases and isolated tumor cells in sentinel and nonsentinel lymph nodes of colon cancer patients. World J Surg 2005;29:1172-1175.

$\checkmark 20$ Redston M, Compton CC, Miedema BW, et al: Analysis of micrometastatic disease in sentinel lymph nodes from resectable colon cancer: results of Cancer and Leukemia Group B Trial 80001. J Clin Oncol 2006;24: 878-883.

-21 Saha S, Seghal R, Patel M, et al: A multicenter trial of sentinel lymph node mapping in colorectal cancer: prognostic implications for nodal staging and recurrence. Am J Surg 2006;191:305-310.
-22 Rosenberg R, Friederichs J, Gertler R, et al: Prognostic evaluation and review of immunohistochemically detected disseminated tumor cells in peritumoral lymph nodes of patients with pN0 colorectal cancer. Int J Colorectal Dis 2004;19:430-437.

-23 Latza U, Niedobitek G, Schwarting R, et al: Ber-EP4: New monoclonal antibody which distinguishes epithelia from mesothelial. J Clin Pathol 1990;43:213-219.

24 Tanabe T, Nishimaki T, Watanabe H, et al: Immunohistochemically detected micrometastasis in lymph nodes from superficial esophageal squamous cell carcinoma. J Surg Oncol 2003;82:153-159.
25 Hermanek P, Hutter RV, Sobin LH, et al: International Union Against Cancer. Classification of isolated tumor cells and micrometastasis. Cancer 1999;86:2668-2673.

26 Feith M, Stein HJ, Siewert JR: Pattern of lymphatic spread of Barrett's cancer. World J Surg 2003;27:1052-1057.

27 Saha S, Bilchik A, Wiese D, et al: Ultrastaging of colorectal cancer by sentinel lymph node mapping technique - a multicenter trial. Ann Surg Oncol 2001;8:94S-98S

28 Stein HJ, Sendler A, Siewert JR: Site-dependent resection techniques for gastric cancer. Surg Oncol Clin N Am 2002;11:405-414.

\section{Announcement}

\section{5th European Gastroenterology and Endotherapy Workshop}

Brussels, Belgium, June 18-20, 2007

The Gastroenterology and Endotherapy European Workshop is intended for practicing gastroenterologists with varying levels of training and experience, for fellows in training as well as GI nurses.

It will include live video demonstrations permitting maximal interaction between faculty and attendees during procedures, using an interactive voting system, evidence-based didactic comments and quizzes. The procedures will be performed by international expert endoscopists in collaboration with radiologists, pathologists and surgeons of the Brussels faculty. Two or three state-of-the-art lectures will be presented every day and illustrated by live video cases allowing comprehensive didactic sessions on almost all range of diagnostic and therapeutic issues.

The aim of these demonstrations is not only to show the new devices and tricks for succeeding in each type of procedure, but above all to explain clearly how to avoid the complications and to offer attractive and interactive discussion on practical cases management and multidisciplinary approach.

This year will be very special since it is the 25 th meeting organized on a yearly basis in Brussels.

Major procedures to be demonstrated: New diagnostic tools in upper and lower gastrointestinal endoscopy; Dilation of gastroin- testinal strictures and stenting; Hemostasis of bleeding ulcers and varices; EUS for staging, FNA; Enteroscopy - double balloon endoscopy; Capsule endoscopy/colonoscopy; Percutaneous gastrostomy and jejunostomy; Mucosal resection and submucosal dissection; All techniques for GERD endoscopic treatment; Zenker's diverticulotomy; Endoscopic treatments in obesity; Endocystoscopy, confocal endoscopy; Therapeutic ERCP; Therapeutic EUS - transmural anastomoses - pseudocyst drainage; Extracorporeal shock wave lithotripsy; Transjugular liver biopsies, TIPS; Percutaneous transhepatic cholangiographies.

Official language: English (no simultaneous translation).

Location: Brussels Exhibition Centre (Auditorium 2000), Belgium.

Course directors: Jacques Deviere, Nadine Bourgeois, Michel Cremer, Olivier le Moine, André van Gossum. Medico-Surgical Department of Gastroenterology and Hepato-Pancreatology, Erasme Hospital, Université Libre de Bruxelles.

For further information:

Mrs Nancy Beauprez, Course Coordinator

Gastroenterology Department, Erasme Hospital

Route de Lennik 808

BE-1070 Brussels (Belgium)

Tel. +3225554900

Fax +32 25554901

E-mail beauprez@ulb.ac.be

http://www.live-endoscopy.com 